\title{
"The Sky is the Limit": Saudi Youth in a Changing Kingdom, Beyond Narratives, Interpretations and Misperceptions
}

\author{
Annalisa Pavan ${ }^{1, *}$ \\ ${ }^{1}$ Department of Philosophy, Sociology, Education and Applied Psychology, University of Padova, Italy \\ *Correspondence: Dipartimento FISPPA, Università degli Studi di Padova, via B. Pellegrino 28, 35137 Padova, Italy. \\ Tel: 39-049-827-1709. E-mail: annalisa.pavan@unipd.it
}

Received: April 30, 2020

Accepted: March 8, 2021 Online Published: May 12, 2021

doi:10.5430/wjss.v8n2p1

URL: https://doi.org/10.5430/wjss.v8n2p1

\begin{abstract}
Current coverage by Western media of Saudi Arabia and Saudi youth conveys a range of narratives, interpretations and misperceptions about the ongoing changes in the country. In particular, this study intends to highlight how the young leadership, led by Mohammed bin Salman, is implementing a new "cultural diplomacy" inspired by foreign consultancies and outlined in Saudi Vision 2030. However, it seems that the actual moral and cultural impact of such diplomacy on the young, educated, connected and often unemployed Saudi youth is not a matter of official concern. This study draws on official Saudi and non-Saudi documents, facts and figures, press reports and recent literature rather than on field research, in the belief that changeable expectations and aspirations expressed by Saudi youth in the $\mathrm{MbS}$ era may be influenced by readily accepted narratives forged both inside and outside the country.
\end{abstract}

Keywords: cultural diplomacy, general entertainment authority, MiSK, Mohammed bin Salman, Saudi Vision 2030

\section{Introduction: Propagandists, Attackers, Observers}

Those who in 2020 are writing and conducting research on the Kingdom of Saudi Arabia can be divided broadly into two groups. Group number one consists of those who, regardless of their nationality, could be termed propagandists, that is, people (journalists, politicians, diplomats, lesser academics, analysts, pundits and members of think-tanks) who are on the very generous Saudi payroll and therefore expected, or required, to offer unconditional support to Saudi policies. Their task has become especially challenging since the brutal murder of Saudi journalist Jamal Khashoggi in October 2018. Group number two consists of those who, regardless of their nationality, could be termed attackers, that is, people (journalists, politicians, diplomats, lesser academics, analysts, pundits and members of think-tanks) who are on the very generous payrolls of Saudi's political rivals, namely Iran and Qatar, but also Turkey; their task is to attack Saudi policies in all fields, and it has been made immeasurably easier thanks to the inevitable outrage caused by the Khashoggi episode.

The author of this paper feels it important to flag the existence of a third group of people, namely a silent (and often voiceless) minority of professional researchers (usually academics) who, being neither pro nor against Saudi Arabia, are definable as observers, simply studying this controversial country and writing about what they see, based on facts and taking as unbiased a stance as possible. This they are able to do since they receive no funding from Saudi Arabia or its rivals, albeit in the face of various difficulties: little or no financial sponsorship, very limited contacts with typically inaccessible Saudi circles, very limited space in international academic publications, lack of exposure on international media, to name but a few. This inevitably silent minority seeks to assess Saudi policies in different fields in a scholarly and objective way. The present paper takes the position of the observers, holding to the belief that theirs is the best way not only to offer a professional insight into Saudi Arabia youth policies, but also to campaign for the genuine betterment of the Kingdom, away from vested foreign interests and influences.

The role of Western media, and predominantly the US media, has in recent years emerged as unquestionably vital in shaping the image of the Kingdom of Saudi Arabia from the political, social, economic and even religious point of view. Both propagandists and attackers have been happily dancing to the tune dictated by the US media. Consequently, little room has been left for professional, impartially informed and balanced research. 
This study draws on official Saudi and non-Saudi documents, facts and figures, press reports and recent literature rather than on field research, in the belief that changeable expectations and aspirations expressed by Saudi youth in the MbS era may be influenced by readily accepted narratives forged both inside and outside the country.

\section{The Young and Ambitious Saudi Youth's Crown Prince}

The world has become aware of a more assertive Saudi Arabia over the past three years, encouraged seemingly by the combined effect of two major events: the launch of Saudi Vision 2030 on 25 April 2016, and the elevation of Prince Mohammed bin Salman (popularly known as MbS) to the status of Crown Prince on 21 June 2017.

Mohammed bin Salman is the eldest son of King Salman and his third wife. He was born in Riyadh on 31 August 1985. He holds a bachelor's degree in law from King Saud University. After working as personal aide to his father and being appointed state minister in 2014, he was appointed Minister of Defense in January 2015, when his father became the new king, and subsequently was elevated to the status of Crown Prince on 21 June 2017. Since then, coverage of the young MbS on Western media has been impressive. In effect, "in a country long ruled by aging kings, MbS was young, tall and transparently ambitious" (Filkins, 2018).

In April 2016, two days before the launch of Saudi Vision 2030, the Saudi newspaper Arab News offered "insights" into the (then) deputy Crown Prince, the "Royal who believes in change" and "is quietly transforming the Kingdom". In an unprecedented move for prominent Saudi royals, $\mathrm{MbS}$ was photographed, bare-headed and in a plain white gown, at his desk and in different rooms of the royal compound in Riyadh. Interviewed by Bloomberg reporters, he unveiled details of his daily life: "He's awakened most mornings by his kids, two boys and two girls, ranging in age from 1 to 6 . That's the last he sees of them. 'Sometimes my wife gets upset with me because I put so much pressure on her for the programs that I want them to have', he says... Prince Mohammed has only one wife and isn't planning on marrying more, he says. His generation isn't so into polygamy, he explains. Life is too busy...Working, sleeping, eating, and drinking don't leave a lot of time to open another household, he says. 'It's tough [enough] living with one family". Talking about his royal upbringing and his generation, MbS said: "We [thirty-somethings] think in a very different way. Our dreams are different". It was reported elsewhere that his favourite pastime is playing the video game Call of Duty (Filkins, 2018).

At a time when MbS was already receiving harsh criticism because of the wars in Syria and Yemen, propagandists hailed the young Minister of Defense as a champion of young vigour and reformism. Attackers, on the other hand, insisted that Saudi Vision 2030 was nothing but another American idea sold as the Saudi, and more specifically the MbS blueprint for the post-oil era. At all events, since 2016 Mohammed bin Salman's rise to power has been unstoppable. Entrusting the creation and exposure of his image in the West to American PR firms, MbS gave a few key interviews that played a pivotal role in establishing his persona as the de facto ruler of Saudi Arabia.

When $\mathrm{MbS}$ is interviewed, his language and approach are surprisingly direct; not typical of Saudi rulers, but in keeping with the language of his generation.

Explaining his vision for the Saudi nation, MbS clarifies that "The most concerning thing is if the Saudi people are not convinced. If the Saudi people are convinced, the sky is the limit" (Ignatius, 2017). Commenting on the need for a "return to a moderate Islam, open to the world and all religions", after the Kingdom has been "not normal" (Chulov, 2017) for the past 30 years, and even "not the real Saudi Arabia" (O’Donnell, 2018), highlighting that "There is no Wahhabism. We don't believe we have Wahhabism" (Goldberg, 2018), the Crown Prince affirms: "70\% of the Saudis are younger than 30 , honestly we won't waste 30 years of our life combating extremist thoughts, we will destroy them now and immediately" (Chulov, 2017). Asked if anything could stop him, MbS replies: "Only death". Replying to criticism about his lavish expenses, the prince puts it bluntly: "I'm a rich person and not a poor person. I'm not Gandhi or Mandela... But what I do as a person is to spend part of my personal income on charity. I spend at least $51 \%$ on people and $49 \%$ on myself".

Commenting on the removal of the ban on women driving, he says: "We are finally over that painful period that we cannot justify." However, he acknowledges that much more remains to be done to improve Saudi women's rights: "Today, Saudi women still have not received their full rights" (O’Donnell, 2018). Asked if he believes in equality for women, he asserts: "I support Saudi Arabia, and half of Saudi Arabia is women. So I support women". However, he is cautious on the troubled issue of male guardianship: "In the 1960s women didn't travel with male guardians. But it happens now, and we want to move on it and figure out a way to treat this that doesn't harm families and doesn't harm the culture", because "Saudis don't want to lose their identity but we want to be part of the global culture. We want to merge our culture with global identity" (Goldberg, 2018). 
Interviewed by Bloomberg a few days after the murder of Jamal Khashoggi, MbS expands on a variety of topics. He states firmly: "Yes, our target in Saudi Arabia is to be competitive. So for example, I have a foundation, I've been trying for the past month to hire a new CEO, a non-Saudi CEO. I can't. Because they don't want to live in Saudi Arabia. That's a problem. Why? Because of the quality of life. And the lifestyle is not good. They want to work one week in Dubai and one week in Saudi Arabia. Come on, what's happening? So we have to reach the best standard as soon as possible to be sure that people can work in this country and can proceed and build things in this country". Moreover, MbS challenges the narratives circulated in the Western media about him: "Actually I didn't call myself a reformer of Saudi Arabia. I am the crown prince of Saudi Arabia and I am trying to do the best that I can do through my position". More specifically, "I don't care how the world views me as much as I care about what's in the interest of the country and the Saudi people. Whatever serves the Saudi people and Saudi Arabia as a country, I will do it with full force, regardless of the impressions that it will create about me. If it's good, thank you, that's great. If it's bad, I will try to clarify myself. If it works, good, if it doesn't work I have to do what's good for my country and for my people" (Flanders et al., 2018). Since 2016, the outspoken Mohammed bin Salman has galvanized Saudi youth and encouraged young ambitions by promoting several initiatives that implement Saudi Vision 2030 in different fields.

\section{MbS' Saudi Youth: Young, Educated, Connected... and Employed?}

From widely circulated data on Saudi youth, cited also by MbS in his interviews, it emerges that typically $70 \%$ of Saudis are younger than 30 . However, according to the latest official statistics made available by the Saudi General Authority for Statistics (at the time of writing, Autumn 2019), these figures are not entirely accurate: out of a total Saudi population of 20,768,627, those in the age group 0-34 number 13,921,811, that is, $67.03 \%$. In addition, $51 \%$ of the Saudi population is under the age of 25. Without doubt the Kingdom of Saudi Arabia today is a predominantly young, emerging country, in contrast to aging Western societies (General Authority for Statistics, 2019 and 2016).

In the 1930s, as reported by various reliable sources, the majority of the population living in the Kingdom was nomadic and the illiteracy rate around $90 \%$. In 1980 the literacy rate was "just over $50 \%$ and was steadily increasing" (Nyrop, 1985). According to UNESCO (2019), the literacy rate of Saudis between 15 and 64 years old is $94.43 \%$, and as high as $99.22 \%$ between 15 and 24 years old.

Today in Saudi Arabia there are 30 public universities, 13 private universities and 42 private colleges (Saudi Ministry of Education website, 2019). In 1970 there were only 3 public universities (King Saud University, King Fahd University of Petroleum and Minerals, King Abdulaziz University). When King Abdullah bin Abdulaziz ascended the throne on 1 August 2005, there were 7 public universities. By the end of 2009, the number of public universities had grown to 24, with the maximum rate of growth, 212.5\%, registering between 1999 and 2009 (Pavan, 2013).

It is estimated that over $80 \%$ of faculty members in Saudi universities have been educated overseas. In fact, Saudi Arabia has by far the oldest tradition among GCC countries of fully government-sponsored scholarships for study at foreign universities. Indeed scholarship-oriented policies have been part of the Al Sauds' education strategy since the 1920s, even before the establishment of the modern kingdom in 1932 (Pavan, 2013). The King Abdullah Scholarship Program (KASP) - launched in May 2005, extended twice and since 2015 in its third stage under the new name Custodian of the Two Holy Mosques' Overseas Scholarship Program - has gained a reputation, over time, as "the most ambitious government-sponsored study abroad project in the Gulf" (Al Tamimi, 2017), despite the troubled transition to the third stage (Pavan, 2017).

According to the National Budget Statement for the Fiscal Year 2019 published by the Saudi Ministry of Finance in December 2018, with total projected expenditure set at SAR1,106 billion ( $\$ 294.9$ billion), spending on the education sector - "public and higher education and workforce training" (p.59) - accounts for around $17.5 \%$ of the total figure, at SAR192.82 billion ( $\$ 51.4$ billion), with an estimated cut in expenditure of $6 \%$ compared to the previous year. At all events, education comes first among the 9 key sectors covered by the budget, followed by the military (SAR191 billion, $\$ 50.9$ billion, with a $12 \%$ cut over the previous year). It is stated that "The Custodian of the Two Holy Mosques' Overseas Scholarship Program will continue. The total number of students sent abroad to study under the supervision of the Ministry of Education has exceeded 196,221 students including their dependents. The number of internal scholarships students amounted to 19,435 students. The annual expenditures on the internal and external programs will be equivalent to SAR14.6 billion [ $\$ 3.8$ billion], excluding scholarships for government entities employees" (p.60). According to the monthly bulletin published by the Scholarship Affairs Agency of the Ministry of Education in February 2019 and reported by Saudi Gazette in March 2019, there are 92, 997 Saudi 
scholarship students overseas (66\% males, 34\% females). 52,038 are students, 18,560 are employees sent on study scholarship, 13,049 are students studying at their own expense, and 9,350 are dependents of scholarship students. Saudi Arabia's college population is forecast to reach a cohort of about four million 18-to-24-year-olds by 2025, up from a little more than three million today (ICEF Monitor, 2018).

According to the Arab Youth Survey 2019, with 23 million active social media users (67\% of the total population), Saudi Arabia ranks fourth behind the UAE, Kuwait and Bahrain (99\%, 92\% and 81\% respectively), and the Saudi youth are globally connected and technologically savvy. However, in a country where information is held under tight control, MbS further clarified three (red) lines in one of his interviews: "In Saudi Arabia we have just three lines anyone can write whatever they want to write, speak about whatever they want to speak about, but they shouldn't reach [sic] these three lines. This is not based on the interest of the government, but on the interest of the people. Line one is Islam. You cannot defame Islam. Line two - ...In Saudi Arabia it's okay to attack a ministry or a company, but the culture of the Saudis, they don't like to attack a person, and they like to leave the personal issue out of it...The third line is national security." And more: "Twitter, Facebook, Snapchat. Name it, it's open for all Saudis. We have the highest percentage of people around the world using social media" (Goldberg, 2018).

Young, educated, connected. And employed? Does a degree, especially when awarded by a foreign university, pay off in today's Saudi Arabia? According to the latest available official figures, in Q4 2018, 39.7\% of all unemployed adult Saudis (age 15+) are male, while $60.3 \%$ are female. The highest unemployment rate among young Saudis is $39.2 \%$, in the age group 25-29, and the next highest, $28.1 \%$ in the age group $20-24$. Also, in terms of educational qualifications, $54.8 \%$ of all unemployed Saudis are holders of Bachelor's degrees, $28.2 \%$ are holders of secondary school certificates (or equivalent) and $0.04 \%$ are PhDs (General Authority for Statistics, 2019).

The current stage of the scholarship program includes an implementation scheme (Your Job and Your Scholarship) under which various government agencies sponsor a number of scholarships and subsequently employ those who graduate in their fields. In theory, all posts are secured for graduates under the Custodian of the Two Holy Mosques' Overseas Scholarship Program. Although the extensive and expensive government-funded scholarship program is seen primarily as a means of enhancing the performance of the Saudi economy, and implementing Saudi Vision 2030, where the government is committed to "closing the gap between the outputs of higher education and the requirements of the job market" (p.40), to date (Autumn 2019) there is no English language document available evaluating the impact of the scholarship program on the Saudi labour market.

As The Economist pointed out in December 2018, Saudi Arabia "needs to create 1.2 million jobs by 2022 to meet its target of 9\% unemployment for Saudi citizens...Though many of them are unemployed, young Saudis ... still speak enthusiastically about Prince Muhammad ... His bold (some say rash) style is popular with them, but it worries investors. Without foreign money the prince will find it difficult to keep all of those young Saudis happy”.

\section{MiSK, GEA, GSA (Ministry of Sport), KSYC}

"At the heart of our vision is a society in which all enjoy a good quality of life, a healthy lifestyle and an attractive living environment"; this can be achieved through "promoting culture and entertainment" and "living healthy", that is, "promoting physical, psychological and social well-being" (Saudi Vision 2030, pp.22-23). In a young country, this vision translates basically into planning and organizing activities for youth and families. If unemployment is a problem, the unemployed (and the underemployed) must at least be kept entertained.

Since 2016, three entities have been charged with implementation of the vibrant society depicted in Saudi Vision 2030: the MiSK Foundation, the General Entertainment Authority and the General Sports Authority (renamed Ministry of Sport in February 2020); another, mentioned less frequently, is the King Salman Youth Center.

The MiSK Foundation (https://misk.org.sa/en/), chaired by MbS, was created in 2011 as a non-profit entity focusing on Saudi youth. It "invests in empowering youth in four main pillars: education, media, culture and technology". To this end, since 2016 MiSK has established its own programs, namely: the MiSK Fellowship, which provides fully-funded scholarships to study at distinguished (i.e. mainly American) institutions abroad; Internships, to take place mainly at US partner institutions; Educational and Corporate Training, same as Internships. The MiSK Art Institute, launched in 2017, and the MiSK Global Forum, held annually since 2016, are the flagship activities of the foundation, trumpeted on a regular basis by international media.

The omnipresent General Entertainment Authority (https://www.gea.gov.sa/en/), the driving force behind the recent waves of new opportunities for entertainment in the Kingdom (cinemas, concerts, shows) chaired by Turki Al Sheikh, presents its activities through its website, under construction for the most part. In the English section it is explained 
briefly that the Authority has been established "to provide exciting entertainment options" and "to contribute in improving and enriching the lifestyle and social cohesion among the community".

Chaired by Prince Abdulaziz bin Turki Alfaisal, the former General Sports Authority, now Ministry of Sport, (https://www.gsa.gov.sa/en/), as in the case of the GEA, is much mentioned by international media (see for example the Formula E event staged in Riyadh, December 2018 and November 2019). Attached to some of these new sport and entertainment events is a new visa system, managed through an online platform on which visitors can apply for an e-visa. People who intend coming from overseas can apply for the visa attached to the particular event. This has been perceived as a very limited step forward in opening up the very strict Saudi visa system. However, since September 2019, Saudi tourist visas have become available to online applicants from 49 countries.

The King Salman Youth Center (www.ksyc.org.sa/?lang=en), chaired by MbS, presents itself as "a non-profit organization founded to support and inspire the youth to build professional leaders and successful entrepreneurs". Neither the Arabic nor the very limited English version of the website provide much help in understanding more about the Center's activities.

\section{Consulting Firms, Consultants, Consulting}

MiSK, GEA, GSA (Ministry of Sport) and KSYC may well reflect the new dynamism of the country and the attention given by the government to youth, but there is ample evidence that they rely heavily for their activities on the advice of foreign (American) consulting firms. Based on official figures, it is very difficult to determine the actual extent of these consulting activities. In the case of the MiSK Foundation, for example, FARA (Foreign Agents Registration Act) filings from January 2018 indicate that two Hill and Knowlton consultants began working with the Foundation in 2017, and put out at least one press release on a youth forum organised jointly by MiSK and the United Nations Development Program in September 2017. Hill and Knowlton is a registered foreign agent for the Saudi Ministry of Economy and Planning and the Saudi Stock Exchange, and also worked on a four-month campaign for World Wrestling Entertainment's foray into Saudi Arabia in 2018. It is also well known that Boston Consulting Group (BCG) is the chief advisor of MiSK (Forsythe, 2018, and Al Monitor, 2019).

Providing consultancy services to the Saudi Kingdom in whatever sphere is certainly a lucrative business. With three American consulting companies at the forefront (Booz Allen Hamilton, McKinsey and BCG), the reliance placed by $\mathrm{MbS}$ on foreign consultants is in line with a long-established tradition in the Arab Gulf countries (Saif, 2016), as he pushes his proposals to revamp the country (Forsythe et al., 2018). A report published in April 2019 provides detailed evidence that Saudi Arabia spent nearly $\$ 15$ million in 2018 on FARA registered firms ( $\$ 27$ million in 2017), for the purpose of lobbying activities with American political entities. As of April 2019, there were nearly two dozen FARA registered firms on the Saudi payroll (Center for International Policy, 2019).

Following circulation of the Executive Summary published by McKinsey in December 2015: "Saudi Arabia beyond oil: the investment and productivity transformation", the doubts that surfaced on international media ("a prince with a plan, or a plan with a prince?": see Ghafar, 2018) are understandable. McKinsey was allegedly paid around \$2 billion to help develop the details of Saudi Vision 2030.

For the purpose of this paper, it is significant that, among the sectors covered by the Vision, specific reference to the youth is nowhere to be found. The Vision depicts the "vibrant society", the "real wealth" of the country, it mentions families, children, the academic and educational system, but it does not explicitly mention youth. So can Saudi Vision 2030 be advertised as the driving force behind the support offered by Saudi youth first and foremost through MiSK, GEA, GSA (Ministry of Sport) and KSYC? No. At any rate not directly.

Saudi rulers insist on the need for the country to preserve its identity and "strong roots" (Saudi Vision 2030, p.18), its cultural heritage and its Islamic role, and at the same time endeavour to turn the Saudi nation into an active member of the globalized society: a globalized Saudi Arabia, but still Saudi Arabia. Princess Reema bint Bandar, President of the Saudi Federation for Community Sports, Head of the Saudi Special Olympics Federation and currently the first female Saudi Ambassador in Washington, has often stressed that the reforms proposed by MbS, especially those concerning women, must be interpreted as "evolution, not Westernization" (Royal Embassy of Saudi Arabia in Rome, 2019). So how to reconcile the role of Western (American) consultancies employed by Saudi Arabian rulers, and the claim for evolution, not Westernization?

While MiSK and the KSYC explicitly target Saudi youth, the same is not true of GEA and GSA. However, given that the majority of the Saudi population is young, the activities of GEA and GSA inevitably impact on youth views and mentalities. 
Fostering creativity among the youth, fighting against unemployment and supporting young talent are all commendable goals, no question. But what cultural and moral models are MiSK, GEA, GSA and KSYC offering to Saudi youth, given that all of them rely on American consultancies?

\section{Saudi Students, Graduates \& Saudi Arabia}

Taking into account the potential impact on Saudi Arabia's economy and society attributable to Saudi graduates from foreign universities, and the emphasis on the need for innovation and creativity that permeates Saudi Vision 2030 and is promoted in particular by MiSK and KSYC, it is inevitable that the actual relationship between research and creativity in Saudi Arabia should attract closer scrutiny. Is the Kingdom a research-conducive environment, where Saudi graduates - especially those from foreign universities - can make good use of the culture of innovation and creativity they learned abroad? Where does creativity stem from? Is Saudi Arabia able to retain its talented youth?

"The effect of the graduates from KASP on research will depend on the number of KASP graduates that join higher education institutes or the country's very few specialized research centres". But "Precise figures on how many KASP graduates are recruited by these institutions are unavailable", "the impact of the KASP on research volume or quality is very limited", and "The national benefits [of the scholarship program] are still unclear" (El-Showk, 2017). Saudi universities in the $\mathrm{MbS}$ era are struggling to climb international university rankings, just as all universities are struggling around the world, but their research has to navigate international academia without crossing the three lines described by MbS. However, research capabilities and creativity are encouraged and can flourish only in a free environment, where free inquiry faces no red lines and free, critical thinking is stimulated and rewarded. Moreover, the products of free research need to be disseminated through international conferences and open round tables, widely circulated publications, free exchange of ideas and collaborative research among scholars from different countries. It is up to Saudi rulers to create the conditions for an effective empowerment of educated youth, who should be able to express their ideas freely and become actively involved in the social and economic development of the country.

Addressing the Chamber of Commerce in Riyadh, May 2018, Prince Turki Alfaisal, former Saudi Ambassador to London and Washington and former director general of the Saudi intelligence agency, explained that communicating and sitting face to face, but also sending students abroad on scholarships, are more effective ways of proceeding than relying on visits by ambassadors and businessmen to market countries, since Saudis have nothing to hide from others: "We cherish our history and our heritage", he concluded. In effect, Saudi students on scholarships are regarded by the Ministry of Education as ambassadors, as they can make a meaningful contribution to promoting the image of the Kingdom in their host countries (Saudi Arabian Cultural Mission in Washington, 2018).

As already explained, the new implementation scheme for the current stage of the scholarship program is aimed at strongly encouraging Saudi graduates from foreign universities to come back to Saudi Arabia and contribute to the socio-economic progress of the country. And indeed "most graduates do return; only $1.3 \%$ of highly skilled Saudis emigrated in 2010, well below the global average rate of 5.3\%" (El-Showk, 2017).

Other authors have noted in the past that "Saudi Arabia has experienced almost no brain drain since it began sending students abroad; virtually all return. Observers ascribe this unusual phenomenon to several factors, including the availability of desirable jobs, the strong ties of family obligation, and the fact that all students abroad are closely supervised by government offices established in each country where Saudis study" (Nyrop et al., 1977). This remark is still valid in 2020 (Pavan, 2020). There are no accurate statistics available on the magnitude of the brain drain in Saudi Arabia, but personal family-related choices (mixed marriages), the economic situation in Saudi Arabia and job market conditions are the reasons for staying away most cited by Saudi graduates who settle down in the US (see for example Saudi Gazette, March 3, 2016).

Not only is brain drain not a matter of official concern in Saudi Arabia, but the Saudi media take much satisfaction in the achievements of Saudi graduates abroad (Al Arabiya, 2016, Arab News, 2018, Arab News, 2019, among others). In other words, the youth may be acting as a very convenient tool in promoting the image and the government of the Kingdom during this time of change.

\section{Cultural Diplomacy: Entertainment Bonanza from Above}

The Khashoggi factor has further fuelled Saudiphobia and sparked outrage among international observers. Scepticism concerning Mohammed bin Salman's bold initiatives and moves in all fields — hailed by the bulk of 
Western media, pundits and think-tanks as "the Saudi revolution from above" (Spiegel Online, 2018) prior to the Khashoggi incident — has risen to a worrying level.

The image of MbS and his Kingdom has been tainted like never before. Prince Turki Alfaisal, interviewed a few weeks after the Khashoggi murder, warned: "The more criticism there is of the crown prince, the more popular he is in the kingdom...That's because Saudis feel that their leader is being unfairly attacked in the foreign media" (Ignatius, 2018). And this is especially true for the youth: attack their crown prince, and it will strengthen their support for their leader; in fact, MbS has undeniably offered more to the young, in terms of social life, than any other rulers before him.

The new wave of "Saudi cultural diplomacy" (Abbas, 2018) started before the Khashoggi murder. The re-opening of cinemas across the Kingdom in April 2018 is among the strategies adopted for economic diversification: the Saudi General Commission for Audiovisual Media (GCAM) announced that it aims to open 2,500 venues by 2030, creating more than 30,000 jobs (Arab News, March 17, 2019). Although it is understandable that "The lifting of the cinema ban opens doors to untrodden ground for investments and lucrative revenue streams for the Kingdom" (Arab News, April 18, 2019), it is regrettable that the cultural level/content of the films, and their impact on the youth, is not a matter of discussion.

The first televised World Wrestling Entertainment in April 2018 and the Kingdom's first ever DJ party in June 2018 attracted both criticism and enthusiasm among young Saudis. Since then, concerts and shows have been organized, often to coincide with sports events, like the Formula E Championship in December 2018 and November 2019. On the occasion of the Formula E Championship in December 2018, Prince Abdulaziz bin Turki declared: "Saudi Arabia is racing into the future... as we open the Kingdom to the world in a transformation that's being supercharged by the Vision 2030 plan" (Arab News, December 15, 2018). Besides praising the government for promoting sports in accordance with Saudi Vision 2030, the prince never fails to highlight the need for private companies to invest in the sports sector (Arab News, March 25, 2019). In short, the promotion of healthier lifestyles, especially for the youth, is always coupled with the economic factor.

The Winter at Tantora festival was the major cultural event between December 2018 and February 2019. Held at the magnificent ancient site of Al Ula, it consisted of a series of themed weekends. A closer look at the details of reservations will show that prices were not affordable for all Saudis, and especially for the young; and the same problem exists with ticket prices at Riyadh's new cinemas (Abualhassan, 2018). The idea behind the great efforts to turn Al Ula into a major tourist destination is underpinned by economic goals: "Our priority is the local community and to provide them with jobs. We want these jobs that we'll create to be filled by the locals first". A scholarship program was launched by the Royal Commission for Al Ula, designed to give local youth the chance to learn abroad about the art of hospitality (Arab News, February 19, 2019).

In February 2019 Turki Al Sheik was in London, where he met a wide range of producers and promoters. On his return he announced the outcomes of "efforts to enrich and diversify the entertainment industry in Saudi Arabia": "a host of international stage shows, musicals, festivals, TV shows, open-air cinema events and other attractions" (Arab News, February 7, 2019). Bill Ernest, former Disney executive and now CEO of the Saudi Entertainment Ventures Co. (SEVEN), declared that Saudi Arabia "is on the brink of a $\$ 64$ billion entertainment revolution", referring to the government's investment plans for developing the entertainment industry over the next decade. "Our offering will create exciting new roles for ambitious young Saudi nationals", he added (Arab News, March 25, 2019).

When Prince Badr bin Abdullah, the Minister of Culture, announced a rich list of cultural initiatives, including fashion weeks, national culinary festival, national theatre, Red Sea International Film Festival, national film archives, to mention just a few - the provision for an artist visa scheme sounds particularly promising, but it is unfortunate that the Kingdom has not yet envisaged any visa scheme for research activities - these were promptly advertised in the media as the new Saudi "renaissance" and "a new era of cultural enlightenment" (AlZahrani, 2019), and he added that the ministry "intends to create an environment that supports national talents in all areas and sectors, and to preserve the country's culture and wealth", explaining that "For our children, we will build a Saudi Arabia where their creative spirits can flourish, confident in their past, stepping out into the future and into the world" (Arab News, March 28, 2019). A US-inspired renaissance for Saudi Arabia that will ensure Saudi youth do not neglect their traditional values? A big challenge lies ahead.

\section{Youth Empowerment?}

For professional researchers who observe the Kingdom from outside, it is difficult to get the real picture behind the 
rose-tinted version offered by the local media (see for example BCG's Jeel Tamooh in March 2019, an event designed to train young nationals to become qualified young leaders: "The Jeel Tamooh event was a reflection of the sentiments of Saudi Arabia's youth", the Saudi Gazette pronounced, March 30, 2019), routinely echoed and magnified by Western media. Due to limitations on freedom of expression - very partially offset by the GCC youth's propensity for adopting social media as new avenues for self-expression (Ghaffar, 2014) — gratitude and conformity are expected from the youth in return for what the government is providing.

Unemployed Saudi youth, who struggle to deal with new taxes and subsidy cuts, are not only unable to afford the average ticket prices they should be paying to enjoy the new culturally vibrant scene (cinemas, concerts, sport events etc), but also, and more importantly, they find it difficult to accept the new privatization policies implemented by the government in a country where two thirds of employed people work in the public sector and roughly half the native population is eligible for monthly payments under the support program for low- and middle-income families. Consequently, "Convincing young Saudis that the state should no longer be the main employer 'is significantly more difficult than allowing concerts"' (Nereim et al., 2018). Massive investments in the entertainment sector, which are challenging "the closed nature of Saudi Arabia and its cultural introversion" (Al-Otaibi, 2019), cannot be effective top-down reforms, as top-down reforms "must be coupled with bottom-up involvement by Saudi youth in reforms that impact their presence and influence in society": in politics, the labour market, welfare, healthcare and the legal system. "A potent amalgamation of factors not only makes this generation of Saudi youth unique, but also creates new challenges and aspirations that policymakers must address... Youth are yearning for an active role in national decision making, while challenging outdated norms and traditions" (Althari, 2018).

Saudi youth in 2020 have the education, the capability, the tools and the willingness to discuss the decision-making of their country, but are not entitled to express themselves freely, which hampers an effective societal transformation beyond "past alienation and repression" (Althari, 2018). And the new "cultural diplomacy", in the short term, may be a stratagem to achieve economic development, although it could turn out in the medium term not to be the right strategy in furthering the social progress of the country.

\section{Conclusion: Saudi Youth beyond Narratives, Interpretations and Misperceptions}

Coverage by Western media of Saudi Arabia and Saudi youth conveys a range of narratives, interpretations and misperceptions. This paper is intended as a tool that can be used to dismantle at least some of the more misleading. The narrative built and most widely circulated by the media in the West is that the young Crown Prince is a reformer: he himself denies this role. In particular, this 'reformer' narrative fails to capture the disengagement and frustration of young unemployed Saudis, and most notably the foreign-educated. Interpretations abound. There are signs that the relationship between the establishment and religious leaders is under review, and indeed Saudi Arabia is evolving and changing, but there is no revolution in sight. Whilst the much celebrated Saudi Vision 2030 is essentially the work of McKinsey, the fact remains that the Saudi establishment has embraced it, which means there is acute awareness of the need to ensure the country advances economically and socially, and to build a future for its youthful population (AlFaisal, 2019). Misperceptions are usually based on the celebration of the new cultural diplomacy implemented by the establishment. In effect, music, shows, cinemas, sports events, even gender-mixing at concerts may give the idea of an open-to-all Kingdom, similar (but not identical) to neighbouring GCC countries. Regrettably, whilst the current cultural openness, inspired and managed by foreign consultancies for the most part, is attractive and helps to appease the population, especially the young, the reality is that basic red lines are still firmly in place and fully enforced, and serious issues (unemployment, housing, human rights advocacy, women's empowerment, economic diversification, to name but a few) need to be tackled more effectively.

In conclusion, three points can provide subject matter for further research.

One: it remains to be seen if the Saudi establishment will be willing and able to make this new status quo (social, economic and cultural reforms) sustainable, not least considering that it will have to be kept in line with the Kingdom's strong Islamic roots, as stressed in Saudi Vision 2030.

Two: MbS will have to find a way to turn his popularity among young Saudi men and women into a political force, given that with a long reign ahead of him as king of a globalized Saudi Arabia, he will inevitably need their staunch and enduring support. During an economic forum held in Riyadh in October 2018, the Crown Prince said: "[Within the next few years] The Middle East will be the new Europe". US-led Western media conveniently omitted to report and comment on this affirmation. Although MbS did not expand on this point, when reminded of the dream to transform the Middle East into a new Europe, he later confirmed: "We must not become hostages of temporary 
conditions that prevent us from fulfilling our primary duty, as leaders in the region, of reviving our states" (Asharq Al Awsat, June 16, 2019). It will be interesting to see if and how the government gives substance to this prediction.

Three: the great challenge for the Saudi youth of today, and more tellingly for the Saudi youth of tomorrow, will be to find their own way far beyond the advice of foreign consultants - not an easy task — and express their views, capabilities and ambitions, as well as their aspirations for their society, political system and domestic labour market. Likewise in the world of international academia, their presence and opinion has been long awaited, as young Saudi academics could provide an invaluable insight into their culture. Their views could also be of help in bringing about a peaceful and wise evolution of the country. Saudi youth have a major role to play in countering "the populist simplifications and corrupted understandings of the country" (Al-Otaibi, 2019).

An earlier version of this paper was presented at the 10th Gulf Research Meeting (GRM), 15-18 July 2019, which was organised by the Gulf Research Centre Cambridge at the University of Cambridge.

\section{References}

Abbas, F. J. (December 29, 2018). Winter at Tantora, but a spring for Saudi cultural diplomacy. Retrieved 1 April, 2019 from www.arabnews.com/node/1427606

Abualhassan, F. (June 11, 2018). Saudi Arabia, A "Revolution" From Afar. Retrieved 13 June, 2018 from https://orientxxi.info/magazine/rewriting-the-narrative-of-saudi-arabia-s-social-revolution,2504

Al Arabiya. (October 31, 2016). Meet the female Saudi rocket and space engineer. Retrieved 26 April, 2019 from https://englishalarabiya.net/en/2016/10/31/Meet-the-female-Saudi-rocket-and-space-engineer-.html

Al Monitor. (2019). Middle East lobbying updates. Weekly Newsletter from Newsletter@al-monitor.com

Al Tamimi, S. A. (2017). Reshaping Higher Education in the Gulf States: Study Abroad Trends and Student Experiences. Gulf Affairs, Spring 2017, 10-13.

Alfaisal, HRH Prince Turki. (2018). Archaeological Components and Scholarships Abroad are Among the Best Means to Promote the Concept of Marketing Homelands. Retrieved 8 June, 2018 from http://www.kfcris.com/en/news/read/124

Alfaisal, HRH Prince Turki. (2019). German-Arab Gulf Dialogue on Security and Cooperation. Retrieved 2 July, 2019 from http://www.kfcris.com/en/news/read/184

Al-Otaibi, N. (2019). The public diplomacy paradox: Saudi Arabia's negative image in the UK. In Koleilat Khatib, D. \& Maziad, M. (Eds), The Arab Gulf States and the West. Perceptions and Realities - Opportunities and Perils, 82-105. Oxon: Routledge. https://doi.org/10.4324/9780429505300-6

Althari, S. (2018). The relationship between Saudi youth empowerment and national development. Retrieved 12 May, 2018

from http://visionofhumanity.org/ambassadors/relationship-saudi-youth-empowerment-national-development-

AlZahrani, H. (March 30, 2019). Modernists in the new Saudi Arabia: A new era of cultural enlightenment. $\begin{array}{lllll}\text { Retrieved } & 1 & \text { April, } & 2019 & \text { from }\end{array}$ https://english.alarabiya.net/en/views/news/middle-east/2019/03/30/Modernists-in-the-new-Saudi-Arabia-A-ne w-era-of-cultural-enlightenment-.html

Arab News. (April 23, 2016). Royal, who believes in change, is quietly transforming Kingdom (printed edition).

Arab News. (July 1, 2018). FaceOf: Adah Almutairi, scientist and entrepreneur. Retrieved 26 April, 2019 from www.arabnews.com/node/1331551/saudi-arabia

Arab News. (December 15, 2018). Saudi Arabia 'racing into the future' with Formula E. Retrieved 1 April, 2019 from www.arabnews.com/node/1420971/saudi-arabia

Arab News. (February 7, 2019). Huge entertainment boost for Saudi Arabia during GEA chief's visit to London. Retrieved 1 April, 2019 from www.arabnews.com/node/1448356/saudi-arabia

Arab News. (February 19, 2019). Al-Ula Royal Commission launches second phase of university scholarship program. Retrieved 1 April, 2019 from www.arabnews.com/node/1455051/saudi-arabia

Arab News. (February 21, 2019). TheFace: Basma Alshaalan, diplomat at Saudi Arabia's UN mission. Retrieved 26 
April, 2019 from www.arabnews.com/node/1456106/saudi-arabia

Arab News. (March 17, 2019). Saudi film forum raises curtain on new-look cinema. Retrieved 1 April, 2019 from www.arabnews.com/node/1468156/saudi-arabia

Arab News. (March 25, 2019). Leisure chief hails Saudi Arabia's \$64 billion entertainment revolution. Retrieved 1 April, 2019 from www.arabnews.com/node/1472066/business-economy

Arab News. (March 25, 2019). Strong sports industry key to boosting Saudi economy. Retrieved 1 April, 2019 from www.arabnews.com/node/1472491/saudi-arabia

Arab News. (March 28, 2019). Saudi Arabia launches cultural transformation. Retrieved 1 April, 2019 from www.arabnews.com/node/1473796/saudi-arabia

Arab News. (April 18, 2019). A magical first year at the movies as Saudi cinemas herald big screen revival. Retrieved 18 April, 2019 from www.arabnews.com/node/1484156/saudi-arabia

Arab Youth Survey. (2019). A Call for Reform. 11th Annual ASDA’A BCW Arab Youth Survey 2019.

Asharq Al Awsat (June 16, 2019). Mohammed bin Salman to Asharq Al Awsat: We Don't Want War but We Won't Hesitate in Dealing with Any Threat. Retrieved 17 June, 2019 from https://aawsat.com/english/home/article/1769696/mohammed-bin-salman-asharq-al-awsat-we-don\%E2\%80\%99 t-want-war-we-won $\%$ E2\%80\%99t-hesitate-dealing

Center for International Policy. (2019). The Saudi Lobby in 2018.

Chulov, M. (October 24, 2017). I will return Saudi Arabia to moderate Islam, says crown prince. Retrieved 17 March, 2019 from https://www.theguardian.com/2017/oct/24/i-will-return-saudi-arabia-moderate-islam-crown-prince

El-Showk, S. (2017). Reaping knowledge: A world away. Retrieved 25 February, 2018 from https://www.nature.com/articles/549S64a

Filkins, D. (2018). A Saudi prince's quest to remake the Middle East. Retrieved 17 March, 2019 from https://www.newyorker.com/magazine/2018/04/09/a-saudi-princes-quest-to-remake-the-middle-east

Flanders, S. et al. (October 6, 2018). Saudi Crown Prince Discusses Trump, Aramco, Arrests: Transcript. Retrieved 6

October, 2018 from https://www.bloomberg.com/news/articles/2018-10-05/saudi-crown-prince-discusses-trump-aramco-arrests-tran script

Forsythe, M. et al. (November 4, 2018). Consulting Forms Keep Lucrative Saudi Alliance, Shaping Crown Prince's $\begin{array}{lllll}\text { Vision. } & \text { Retrieved } & 18 & \text { March, } & 2019\end{array}$ https://www.nytimes.com/2018/11/04/world/middleeast/mckinsey-bcg-booz-allen-saudi-khashoggi.html

General Authority for Statistics, Kingdom of Saudi Arabia. (2016). Demography Survey 2016.

General Authority for Statistics, Kingdom of Saudi Arabia. (2019). Labor Market. Fourth Quarter, 2018. Retrieved 1 May, 2019 from https://www.stats.gov.sa/en/6443

General Authority for Statistics, Kingdom of Saudi Arabia. (2019). Population by Gender, Age Groups and Nationality (Saudi/Non-Saudi). Retrieved 18 March, 2019 from https://www.stats.gov.sa/en/5680

General Authority for Statistics, Kingdom of Saudi Arabia. (2019). Population Estimates. Retrieved 18 March, 2019 from https://www.stats.gov.sa/en/5680

Ghafar, A. A. (February 14, 2018). A New Kingdom of Saud? Retrieved 25 February, 2018 from https://www.brookings.edu/research/a-new-kingdom-of-saud/

Ghaffar, M. A. (2014). Social Media: Impacts on Arabian Gulf Youth and Governments. In Al-Zoby, M. A. \& Baskan, B. (Eds.), State-Society Relations in the Arab Gulf States (pp. 61-76). Berlin: Gerlach Press. https://doi.org/10.2307/j.ctt1df4hq3.6

Goldberg, J. (April 2, 2018). Saudi Crown Prince: Iran's Supreme Leader 'Makes Hitler Look Good'. Retrieved 15 August, 2018

from https://www.theatlantic.com/international/archive/2018/04/mohammed-bin-salman-iran-israel/557036/

ICEF Monitor. (July 18, 2018). Saudi Arabia's expanding higher education capacity. Retrieved 24 March, 2019 from http://monitor.icef.com/2018/07/saudi-arabias-expanding-higher-education-capacity/ 
Ignatius, D. (2017, April 20). A young prince is reimagining Saudi Arabia. Can he make his vision come true? $\begin{array}{lllll}\text { Retrieved } & 20 & \text { April, } & 2017 & \text { from }\end{array}$ https://www.washingtonpost.com/opinions/global-opinions/a-young-prince-reimagines-saudi-arabia-can-he-ma ke-his-vision-come-true/2017/04/20/663d79a4-2549-11e7-b503-9d616bd5a305_story.html?utm_term=.6122d7 c3263b

Ignatius, D. (October 24, 2018). The Saudi royal family circles its wagons in the Khashoggi crisis. Retrieved 25 October, 2018 from https://www.washingtonpost.com/opinions/global-opinions/the-saudi-royal-family-circles-its-wagons-in-the-kh ashoggi-crisis/2018/10/2433a72d8a-d79c-11e8-aeb7-ddcad4a0a54e_story.html

Kingdom of Saudi Arabia. (2017). Saudi Vision 2030. Retrieved 2 January, 2017 from vision2030.gov.sa/en

McKinsey Global Institute. (2015). Saudi Arabia beyond oil: The investment and productivity transformation. Executive Summary.

Ministry of Education, Kingdom of Saudi Arabia. (2019). State Universities - Private Higher Education Universities - Private Higher Education Colleges. Retrieved 26 April, 2019 from https://www.moe.gov.sa/en/HigherEducation/governmenthighereducation/StateUniversities/Pages/default.aspx; https://www.moe.gov.sa/en/HigherEducation/PrivateHigherEducation/Pages/PrivateHigherEducationUniversitie s.aspx;https://www.moe.gov.sa/en/HigherEducation/PrivateHigherEducation/Pages/PrivateHigherEducationCol leges.aspx

Ministry of Finance, Kingdom of Saudi Arabia. (2018). Budget Statement. Fiscal Year 2019.

Nereim, V., \& Algethami, S. (January 29, 2018). Some Saudi Millennials Won't Dance to Their Young Prince's Tune. Retrieved $15 \quad$ August, 2018 from https://www.bloomberg.com/news/articles/2018-01-29/some-saudi-millennials-won-t-dance-to-their-young-prin ce-s-tune

Nyrop, R. F. et al. (1977). Area Handbook for Saudi Arabia. American University, Foreign Area Studies. Research completed May 1976.

Nyrop, R. F. (Ed). (1985). Saudi Arabia. A country study. American University, Foreign Area Studies. Research completed March 1984 under the Country Studies/Area Handbook program sponsored by the Department of the Army.

O'Donnell, N. (March 19, 2018). Saudi Arabia's heir to the throne talks to 60 minutes. Retrieved 17 March, 2019 from https://www.cbsnews.com/news/saudi-crown-prince-talks-to-60-minutes/

Pavan, A. (2013). A New Perspective on the Quest for Education: the Saudi Arabian Way to Knowledge Society. Higher Education Studies, 3(6), 25-34. http://dx.doi.org/10.5539/hes.v3n6p25

Pavan, A. (2017). The Custodian of the Two Holy Mosques' Overseas Scholarship Program: Targeting Quality and Employment. World Journal of Education, 7(4), 32-39. http://dx.doi.org/10.5430/wje.v7n4p32

Pavan, A. (2020). Higher Education Abroad in the New Millennium: GCC Scholarship Programs as GCC Culture and Identities Boosters. Saudi Arabia in the Spotlight. In Karolak, M. \& Allam, N. (Eds.), Gulf Cooperation Council Culture and Identities in the New Millennium: Resilience, Transformation, (Re) Creation and Diffusion, 221-243. New York: Palgrave Macmillan. https://doi.org/10.1007/978-981-15-1529-3_12

Royal Embassy of Saudi Arabia in Rome, Italy. (February 24, 2019). Princess Reema bint Bandar nominata Ambasciatrice a Washington, con rango di Ministro. Retrieved 26 April, 2019 from www.arabia-saudita.it/news.php?id $=1130$

Saif, S. (2016). When Consultants Reign. Retrieved 2 April, 2019 from https://www.jacobinmag.com/2016/05/saudi-arabia-aramco-salman-mckinsey-privatization/

Saudi Arabian Cultural Mission in Washington. (2018). SACM Clubs. Retrieved 11 March, 2018 from sacmclubs.org/en/site/page/view/aboutsacmclubs

Saudi Gazette. (March 3, 2016). Many Saudi students settle down in US; reasons differ. Retrieved 3 March, 2016 from http://saudigazette.com.sa/saudi-arabia/many-saudi-students-settle-down-in-us-reasons-differ/

Saudi Gazette. (March 3, 2019). 92,997 scholarship students overseas; Canada not on list. Retrieved 24 March, 2019 from saudigazette.com.sa/article/560356 
Saudi Gazette. (March 30, 2019). Saudi talent at 'Jeel Tamooh' amazing, say organizers. Retrieved 1 April, 2019 from saudigazette.com.sa/article/562316

Spiegel Online. (May 14, 2018). Revolution from Above. Prince bin Salman Drags Saudi Arabia into Modernity. Retrieved $14 \quad$ May, 2018 from http://www.spiegel.de/international/world/saudi-arabian-crown-prince-launches-revolution-from-above-a-12058 16.html

The Economist. (December 18, 2018). Saudi Arabia's economic reforms are not attracting investors. Retrieved 18 December, 2018 from https://www.economist.com/middle-east-and-africa/2018/12/18/saudi-arabias-economic-reforms-are-not-attracti ng-investors

\section{Copyrights}

Copyright for this article is retained by the author(s), with first publication rights granted to the journal.

This is an open-access article distributed under the terms and conditions of the Creative Commons Attribution license (http://creativecommons.org/licenses/by/4.0/). 